\title{
Social Responsibility Business as a Modern form of Business Ethics
}

\author{
Jolanta PAKULSKA ${ }^{1}$, Małgorzata RUTKOWSKA ${ }^{2}$ \\ ${ }^{1}$ Cardinal Stefan Wyszyński University in Warsaw, Warsaw, Poland \\ ${ }^{2}$ Wroclaw University of Science and Technology, Wroclaw, Poland \\ malgorzata.rutkowska-podolowska@pwr.edu.pl
}

\begin{abstract}
Corporate social responsibility (CSR) only recently found its foothold in the businesses, therefore there is not a single definition that would describe what the business social responsibility really is. That is why the authors choose to illustrate the numerous definitions of this notion that are present in subject literature. In the light of the growing importance of corporate social responsibility many organizations and institutions, both on national and international level, took measures to promote this idea. Further section of the paper is devoted to those initiatives. In summary: the authors discuss the topic of CSR development in Poland. The origin of this idea in our country dates back to 2001, to the Global Compact initiative. Ever since then there are actions aiming at developing this idea, both on governmental and NGO levels, as we have since witnessed the creation of NGOs promoting the CSR idea in our country. What is also worth stressing is the presence of one of world's few RESPECT stock exchange indexes, which indicate corporate involvement in CSR. The paper aims to explain business social responsibility. The study uses the descriptive methods. It consists of isolating and describing the respective approaches to business social responsibility.
\end{abstract}

Keywords: Corporate Social Responsibility, Index RESPECT, ISO 26000, Stakeholder.

\section{The development of corporate social responsibility}

The origins of corporate social responsibility (CSR) date back to the 1930s. Then, in the United States of America for the first time people considered that business in addition to their goals should be also responsible for what is happening in its environment. About 20 years later, in the 1950s, there has been a further thought on the features of companies in today contemporary economy. Then there is Howard R. Bowen has defined "social responsibility" as „the obligations of businessmen to pursue those policies, to make those decisions, or to follow those lines of action which are desirable in terms of the objectives and values of our society" [1]. Spreading this idea in business had to wait yet another 40 years and only since the 
1990s companies have increasingly noted its role both as a basic element of the economic system, as well as promoting social development in all its aspects. The action of this scope took place first in the United States of America, Western Europe and Japan, and then, with the development of the process of globalization, has started to spread to other countries. Corporations from those countries share their ways of doing business, including the idea of corporate social responsibility, to other areas. In this way also the CSR was transferred to companies in Poland.

The company's socially responsible are mainly companies that comply with applicable law. Of course, this is not a sufficient condition, because the law is required by legitimate organizations. In addition, socially responsible organizations voluntarily take into account in its activities the societal interests, protect the environment and maintain good relations with all stakeholders. Stakeholder is the one on whom the organization of their activities affected, as well as whoever the activities of the organization affected. Responsibility as effective management strategy is based on social dialogue at the local level, contributes to the growth of competitiveness at the global level and at the same time shapes the conditions for sustainable social and economic development [5].

In 1991, Carroll presented his CSR model (see fig. 1) as a pyramid and suggested that, although the components are not mutually exclusive, the manager should see that the different types of obligations are in constant tension with one another. Carroll suggested a model that contains the following four categories of corporate responsibility in decreasing order of importance: economic - being profitable, legal obeying the law, ethical doing what is right and fair and avoiding harm, discretional / philanthropic being a good corporate citizen.

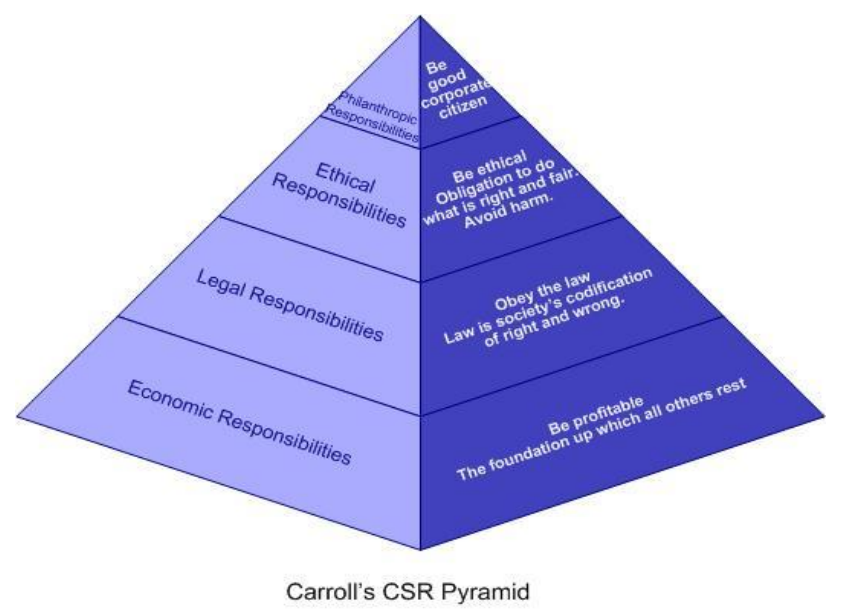

Fig. 1. Carroll's CSR Pyramid [3]. 
In the literature there are two dimensions of corporate social responsibility. The first one is internal and covers:

- the management of human resources (equality of workers, workers participation, that is, employee involvement in decision-making, the development and improvement of qualifications, fair wages, supporting employees in balancing family responsibilities with work),

- the ethical programs for employees (e.g. ethics, ethics training, the appointment of the Ombudsman, affairs ethics, procedures in the event of a breach of the code of ethics),

- health and safety at work, quite often defined as safety in the workplace (e.g. in addition to the required by law - safety work in the enterprise, various forms of health care for employees),

- the ability to adapt to change (e.g. to taking into account the interests of all the parties in the case of restructuring, so as to minimize its negative effects, employment flexibility, the policy of releasing employees - for example: outplacement),

- environmental management (e.g. reducing consumption of energy, water, waste management procedures which allows the systematic reduction of negative company's impact on the environment); principles of corporate governance (e.g. transparency of information, the ways of the appointment and remuneration of supervisory board members).

The second, external, is covering:

- the local community, often referred to as the impact on local society (e.g. principles of cooperation with non-governmental organizations and other local partners, employee volunteer work, commitment to the chemteam, civic engagement, social investment),

- relationships with suppliers and customers, e.g. compliance with the timeliness of delivery and payment to suppliers, [19] monitoring quality, efficiently responding to customer complaints, and other partners, specifying the requirements associated with the use of systems of corporate social responsibility by suppliers or subcontractors, taking into account social and environmental aspects of commercial decisions, providing products and services of safer for the environment and people, anti-corruption); human rights, e.g. the commitment of companies to respect human rights no child labour, forced labour, non-compliance creating equal opportunities, fair trade policy); global environmental problems or the environment, for example: the greenhouse effect, climate change, technology to reduce the consumption of non-renewable resources [12]. 


\section{The concept of corporate social responsibility - review of the definition}

So far there is over one definition of that concept. Literature provides many different definitions of the concept of corporate social responsibility. International organizations or national institutions emerging in order to promote CSR and international initiatives are stated in their definitions. So you can read that "corporate social responsibility is a concept which holds that the company is responsible to the social environment for the consequences of their actions. Social environment includes all persons, groups of persons, organizations that receive directly the effects of enterprise activities or indirectly are interested in them" [11]. According to another definition social responsibility is described as the moral responsibility and obligation to account for its activities before the public [22]. Speaking of corporate social responsibility it can also be stated that this is "philosophy, which says that the company is a creation of society and as such should be involved in the initiatives of its local community; the company management should undertake such decisions and actions that contribute to both care for the interest of their own (as profit), as well as protection and to increase is social welfare" [5].

Canadian Commission for democracy and Responsibility corporate social responsibility defines as "the whole business relationship with all relevant stakeholders. This includes customers, employees, community groups, suppliers, owners/investors and competition" [2].

The World Business Council. Sustainable Development considers social responsibility for ethical behaviour, which is contributing to the economic development, which will be accompanied by improving the quality of life for workers and their families, the local community and society as a whole. It defines the social responsibility of business as a "continuous commitment of business to the ethical behaviour and contribute to economic development, while improving the quality of life of the workforce and their families, as well as the local community and society as a General" [20].

The European Commission, which has played a big role in the promotion of CSR in the European Union, considers social responsibility as a process in which companies manage their relationships with stakeholders, who can have an impact on their success in business [20]. What's more, the European Commission defines CSR as a concept according to which "the company voluntarily takes account of social and environmental issues in their business operations and relationships with stakeholders" [13]. It thus identified CSR as "the responsibility of enterprises for their impact on society". This impact is of the multidimensional nature and manifests itself not only in the business care environment, employees and working conditions. The role of CSR in today's economy for is to operate on the basis of similar value, seeing people in the processes of production, distribution and consumption and the implementation of the principles of corporate social responsibility in all areas of operation of the company [8]. One of the categories of CSR is the environment in which the company should engage in activities such as: reducing emissions, waste 
management, wastewater management, limiting the consumption of energy and water consumption, etc.

Very important also the CRS definition determined by the standard quality, the ISO 26000. ISO 26000 is the international standard containing guidance on liability for the consequences of its activities visible in the society and the environment. This standard specifies that companies should take into account their activities, the Organization governance, human rights, worker rights, environmental issues, fair operating practices (e.g. fair competition or anti-corruption), consumer issues and social commitment and the development of the local community. ISO 26000 approved on 1st November 2010, indicates that "the strategy in terms of responsible influence on actions and decisions (products, services, processes) on society and the environment, through transparent and ethical behaviours that contribute to the development of sustainable prosperity, health, taking into account the expectations of stakeholders, law, consistency with the organisation [9].

Corporate social responsibility, ISO 26000, the commitment "of the Organization for the inclusion of social and environmental aspects in the process of making decisions and taking responsibility for the impact on decisions and activities on society and the environment. This means the behaviour of transparency and ethics, contributing to sustainable development, in accordance with applicable law and consistent with international standards. In other words, corporate social responsibility is built into the structure of your organization, practiced in its activities and takes into account the expectations of stakeholders" [4]. ISO 26000 is not a corporate social responsibility, but is kind of a guide how to make CSR.

The common element in all definitions is a broad category of stakeholders, that is, all those that in any way affects the activity of the company (that is, not only shareholders, but also the natural environment or the local community) and taking into account the interests of stakeholders by the socially responsible in their activities and reconciliation of sometimes conflicting interests of individual groups.

Regardless of different definitions and approaches it is assume that the corporate social responsibility means business socially credible, transparent, taking into account ethics and right, in the sense of responsibility for society, customer, environment, employee and investor. Caring for the natural environment takes a very important place in these ideas. With the implementation of CSR principles it is possible to build a positive image of the company and gain the trust and loyalty of its stakeholders, i.e. employees, customers, partners.

\section{Initiatives to promote CSR}

The increase in the role of corporate social responsibility gave rise to many international and national organizations to promote this idea. The first initiative in this area was the round table in Caux (1989). It's made up of leading business representatives from Europe, the USA and Japan. The merit of this initiative was the adoption of a global policy in business, which involved running a business based on 
ethical, with due respect for the rules in force in the countries of conducting business [15]. The Codex included general rules:

- "Responsibility: from liability to shareholders towards the concept of accountability to the stakeholders.

- Economical and socially responsible business impact: towards innovation, justice and the community.

- Business behaviour: going beyond the letter of the law to the spirit of trust

- Respect for the rules of law.

- Support for multilateral trade.

- Respect for the environment.

- Avoiding activities contrary to the law" [15].

In addition, the code also includes detailed rules that describe the basic obligations to stakeholders of the company.

A significant role in the promotion and implementation of CSR in the world was created by another initiative, which was taken in 1999 at the World Business Forum in Davos-UN Secretary-General Kofi Annan. It was named the Global Compact. You can join the initiative voluntarily by submitting your business to the SecretaryGeneral of the UNITED NATIONS without having to prove that the company meets certain conditions. GC policies include 4 areas:

- Human rights: business should support and protect internationally recognized human rights, it shouldn't break (or not have) human rights;

- Labour standards: business should support freedom of Association and allow Right to negotiate collective agreements, eliminate all forms of forced labour, work towards the abolition of child labour, eliminate discrimination in employment and work;

- Protection of the environment: business should support preventive actions for the protection of the environment, take action to promote environmental responsibility, encourage the development and spreading of environmentally friendly technologies;

- The fight against corruption: business should work against all forms of corruption [10].

Currently, the GC is the world's largest voluntary initiative (with over 3 thousand companies from more than 100 countries) [14]. With belonging to the GC comes the obligation to develop the "annual report on the progress in the implementation of the ten principle of the Global Compact Initiative for stakeholders). GC includes 74 entities from Poland, the first of which joined the GC in 2001. 
In 2000, the Global Resources Initiative (GRI) published guidelines that defined the indicators of compliance with the principles of responsible business (GRI Sustainable Reporting Guidelines. They have been updated in a year: 2004, 2006 and 2014. GRI include environmental, economic and social indicators. As in the case of the GC there is no way verifying now procedures comply with these guidelines [10].

Promotion of CSR was backed by the European Commission, who in 2001 published a green paper [6] on corporate social responsibility, which were guidelines for GC. The green paper defines the social responsibility of business as a "concept whereby companies voluntarily shall take into account the social and environmental aspects in its activities and in their relations with their stakeholders. Corporate social responsibility is a process by which companies manage relationships with various stakeholders who can have a real impact on the consent to their activities. (...) Thus, CSR should be treated as an investment, not a cost, as well as quality management. Companies can approach to CSR in a financial, commercial and social development, leading to a long-term strategy to limit the risks associated with uncertainty. Companies should carry out its social responsibility, both in Europe and internationally; including in the it supply chains your entire" [6].

What's more, the European Commission in the same year published the white paper "European Governance" (governance in Europe), in which it stressed the need to inform the public about the activities of the company and "green paper on consumer protection in the EU". In the following year (2002) programme actions were taken for the promotion of social responsibility (Corporate Social Responsibility: A Business Contribution to Sustainable Development) [10]. In March 2006, a message was posted under the title: "implementation of the partnership for growth and jobs: making Europe a leader in corporate social responsibility". In 2010, the EC stated that companies are beginning to implement CSR as a way to improve their image [144].

Overview of the most important international initiatives for the promotion of corporate social responsibility is presented in table 1.

Table 1. Overview of the most important international initiatives for the promotion of corporate social responsibility [16]

\begin{tabular}{ll}
\hline \multicolumn{1}{c}{ Initiative } & \multicolumn{1}{c}{ The main assumptions } \\
\hline & $\begin{array}{l}\text { Agenda is a global action programme for the environment and } \\
\text { development, adopted at the Earth Summit in Rio de Janeiro in }\end{array}$ \\
Agenda 21 & $\begin{array}{l}\text { 1992, this Program shows how to balance economic and social } \\
\text { development with respect for the environment. A key role in the } \\
\text { process of implementation of Agenda 21, the local authorities }\end{array}$ \\
& have to play. \\
& Rio Declaration is a collection of 27 fundamental principles of \\
& sustainable development, which define and determine the rights \\
& and obligations of States and citizens to the environment and \\
Declaration of & poverty. Records Declaration, referring to adopted w1982, the \\
Rio Janeiro & world of nature and the Brundtland Report Card from 1987, \\
& included e.g. 6 policy action programmes of the European Union
\end{tabular}


Business card for sustainable development

The OECD guidelines for multinational enterprises

The business rules adopted during the deliberations of the round table of Caux

Global Compact and the European network of cities for sustainable development, and in Poland in the new Constitution (article 5), the statutory definition of sustainable development and in the basic strategic documents and, in particular, in the first (1991) and the second environmental policy (2000).

Business card for sustainable development is a set of 16 principles for creating environmental management systems in enterprises.

The guidelines were developed in order to promote the idea that multinationals have acted in accordance with the policies of the countries in which they operate. Include many aspects of business, such as: transparency of information, competition, employment and employment, environmental protection, the fight against corruption and the protection of consumer interests.

The round table initiative from Caux presents social responsibility in the context of changes in the social, political and economic worldwide. Presents a set of rules based on the fundamental ethical values and defines the basic responsibilities of business in relation to stakeholders such as owners and investors, customers, suppliers, employees, and local communities.

The Global Compact is an initiative of the UN Secretary-General Kofi Annan, which is the call to the business world, to its business, led the 10 fundamental principles from the scope of labour rights, environmental protection and anti-corruption. Provides a unique forum for dialogue and learning. The initiative is not a regulatory instrument or a legally binding code of conduct, but the value of the platform created to promote knowledge about corporate social responsibility. The idea of a Global Compact is expressed in the 10 fundamental principles arising from the Universal Declaration of human rights, the Charter of fundamental legal principles of the International Labour Organization and the Earth Summit in Rio de Janeiro. 10 principles of the Global Compact:

Human rights: the promotion of and respect for human rights, adopted by the international community; elimination of all violations of human rights by the company;

Labour standards: respect for freedom of association, elimination of all forms of forced labour, abolition of child labour, effectively tackling discrimination in respect of employment;

Environment: precautionary approach to environment, implement initiatives to promote environmental responsibility, attitudes the use and dissemination of environmentally sound technologies Anti-corruption: anti-corruption in all its forms, including extortion and bribery

Global Sullivan Principles are a set of rules aimed at ensuring that 
Principles the company will support the economic, social and political justice in the markets in which they operate. Are based mainly on human rights and the promotion of equal opportunities in relation to members of the communities in which the company actively functioning.

Has the task of implementation of the Lisbon strategy of the EU in order to implement the agenda for corporate social responsibility business by launching the European campaign 2005 in the area of corporate social responsibility. The goal of the campaign is to

European Campaign 2005

Green Paper

A renewed EU strategy for 2011-2014 concerning corporate social responsibility 2005500 thousand. Enterprises and partners for action to promote the idea of corporate social responsibility. It is of particular importance for the new EU Member States. It also provides access to solutions in the sphere of management of social responsibility and creates a set of practical instruments needed to use the full potential of the companies related to activities with the principles of corporate social responsibility.

Is a document synthesis the concept of corporate social responsibility at European level? The document defines corporate social responsibility as a concept, which the company voluntarily builds strategies based also on factors taking into account the social interests and the protection of the environment, and relations with stakeholders. The document also stresses the fact that corporate social responsibility can have direct economic importance. Stresses on internal and external dimension corporate social responsibility and the impact on social management and reporting system.

As a result of the call, the Council and the European Parliament resulting from the Europe 2020 strategy, the European Commission has developed a new policy on CSR. The starting point is a strategic approach to corporate social responsibility and to propose, in this connection, the new definition of CSR by KE. This document as a main task, adopt: (1) to improve the visibility of the CSR and dissemination of good practices; (2) improving and monitoring the level of confidence in enterprises; (3) the improvement of processes in the field of self-regulation and coregulation; (4) expansion of solutions, which can compensate for the enterprises to their responsible attitude; (5) improvement of social and environmental issues; (6) giving greater importance of CSR in the context of education, training and research; (7) stressing the importance of national and regional policies in the field of CSR; (8) a better adaptation of European and global approach to CSR. 


\section{Corporate Social Responsibility in Poland}

In Poland, the first initiative on corporate social responsibility took place in 2001, during the first meeting of the Global Compact initiative. The development of CSR becomes especially visible after 2009, when the securities exchange index included RESPECT (it concerns companies with CSR strategies). The index RESPECT was created in November 2009 on Securities, one of the few in Europe and the world index of socially responsible companies. It was designed to increase interest in companies traded honours a commitment to CSR. Companies in the index are examined according to the definition of social responsibility. It is more stable than the other indexes on the stock exchange. The corporate social responsibility (CSR) team was established as a subsidiary body of the President of the Council of Ministers. As a result, the Steering Committee was formed, which incorporated Polish and international companies. This team had the task of promoting CSR, creating better communication and sharing best practices of corporate social responsibility in business and the development of the vision of sustainable development for Polish firms to 2050 [14], also environmental partnership Foundation [20]. In the year 2001 the Forum of responsible business, was held which at the moment is the largest nongovernmental organization in Poland dedicated to promoting the idea of CSR.

It should be pointed out that Poland very actively was involved in the implementation of the idea of corporate social responsibility, as was the formation of agencies, Global Compact and Caux Round Table and creation of industry codes of ethics. The concept of CSR appeared in Poland together with international corporations that have moved their operating principles of the native countries to Poland.

The research made in 2011 by $\mathrm{PwC}$ shows that less than 40 percent polish enterprises engaged in CSR activities and only the 100 biggest companies created a management structure, implemented ethical codes and informed the environment of their activities in the field of CSR [18]. The solutions used the most frequently by the Polish companies at the begging on the twenty-first century are presented in the table 2.

Table 2. Solutions used by companies as part of CSR principles [18]

\begin{tabular}{lc}
\hline \multicolumn{1}{c}{ Solutions used by companies } & $\begin{array}{c}\text { Percentage of } \\
\text { surveyed companies }\end{array}$ \\
\hline Actions undertaken in the interest of customers, such as safety and & 88 \\
quality of goods and services & 85 \\
Activities for local communities & 80 \\
Internal form employee evaluation system & 60 \\
Written code of business conduct & 67 \\
Specific priorities for the company associated with the CSR & 62 \\
Implemented environment protection management system & 60 \\
Report showing business management and implementation of &
\end{tabular}


corporate strategy with regard to socially activities

In a study undertaken by KPMG among top executives and employees responsible for CSR respondent as the most important challenges that should engage the company pointed out the problems related to the environment (99\% of the identified recycling and proper waste management, $97 \%$ in General, protection of the environment). The response to a question about the most significant challenge from the point of view of the company (50\% indicated protection of the environment) is similar. It is important first of all to distinguish between industrial companies, among which such indications amounted to $56 \%$ and companies from the service sector, where such indications were also the highest and significant and amounted to $38 \%$ [7]. Additionally, the authors of the study note that activities in the field of CSR shall take the larges and very large companies with participation of foreign capital. As for as activity of the companies is concerned, most companies encourage not the area that they see as most important, but local communities. The environment is in the second place with a little lower percentage (89\% of the local communities, $85 \%$ support area: environment). Local communities were in the opinion of respondents on the second place in the ranking of validity [7].

Polish companies listed holding CSR strategies take action in this area primarily because of the desire to reduce the impact of its business on the environment (in a scale of 1 to 5 motivation was 4.7). Among the benefits of external benefits of CSR for the company, so improvement of the environment took the highest place (4.2) [17].

\section{Conclusions}

Given the above, it is concluded that consumers attach increasing importance to the responsible conduct of business by the company; increasing the pressure of public opinion, NGOs and civil initiatives enforces respect for the principles of sustainable development through the business; now, with such a wide development of CSR, questioning social responsibility by companies is not likely. Interest in CSR is "fashionable" particularly in the United States of America, as well as in Western Europe, and also it is increasingly present in Poland.

Polish enterprises still do not fully appreciate the importance of CSR. They focus mainly on achieving short-term market goal without a long-term strategic vision. CSR are the long-term strategy, which brings benefits in a long-term perspective. A little different look has a big enterprise, which uses CSR as a strategy to give advantages on the market.

It is worth to add that in Poland a great number of institutions and organizations involved in promoting CSR. This makes the idea of CSR is becoming more and more 
known and popular also among companies in Poland. The implementation of this idea has still been in progress.

The basic issues like environment, ethics, responsibility to stakeholders, by the Polish society and companies are not sufficiently appreciated. It is an important task for the State institutions, non-governmental organizations to popularize this idea.

Currently Corporate Social Responsibility is in Poland so important, so to a large extent affect its functioning, that the representatives of the companies in the vast majority agree as to its further development. CSR has an impact on the operation of the business in Poland, especially in the area of operation of companies, the protection of the environment and the relationship with the community. The involvement of business in solving social problems in Poland over 15 years is a practical acknowledgement of understanding that his duty in addition to generating profit is to build value for all stakeholders.

Progress in the implementation of CSR could be carried out mainly by international corporations, which by opening their headquarters can, at the same time, transfer their international standards. Important for the development of the industry were also increasing demand of more informed business partners and consumers. The biggest barrier to the development of CSR in the past 15 years became a lack of understanding of CSR ideas by firm's managers.

\section{References}

1. Bowen, H.: Social Responsibilities of the Businessman, Harper and Row, New York (1953).

2. Canadian Democracy and Corporate Accountability Commission (2001). An Overview of Issues (2001).

3. Carroll, A.B.: A three-dimensional conceptual model of corporate social performance; Academy of Management Review 4. (1979)

4. CSR społeczna odpowiedzialność biznesu w Polsce. Ministerstwo Gospodarki, Krajowy Program Reform Europa 2020, Warszawa (1979).

5. Gasparski, W.: Wykłady z etyki biznesu, Wydawnictwo WSPiZ, Warszawa (2004).

6. Green Paper Promoting European Framework for Corporate Social Responsibility (2001.07.18). Commission of the European Communities, Brussels, http://ec.europa.eu/employment_social/soc-dial/csr/greenpaper_pl.pdf, last accessed: 2016/10/10.

7. KPMG, http://www.kpmg.com/pl/pl/issuesandinsights/articlespublications/strony/ informacja-prasowa-csr-faktyaopinie.aspx, last accessed 2016/10/10.

8. Ministry of Energy of Poland. http://www.me.gov.pl/Wspieranie+przedsiebiorczosci/ Zrownowazony+rozwoj/Spoleczna+Odpowiedzialnosc+Przedsiebiorstw+CSR, last accessed 2016/02/25.

9. Kapitał społeczny dla gospodarki. O CSR, ISO 26000, www.odpowiedzialnafirma/ocsr/iso-26000, last accessed 2016/09/10.

10. Kietliński, K., Reyes, V.M., Oleksyn, T.: Etyka w biznesie i zarządzaniu, Oficyna Ekonomiczna, Kraków (2005). 
11. Klimczak, B.: Etyka gospodarcza, Wydawnictwo Uniwersytetu Ekonomicznego we Wrocławiu, Wrocław (2006).

12. Klimek, J.: Społeczna odpowiedzialność biznesu, Wydawnictwo Adam Marszałek, Toruń (2012).

13. Komisja Europejska. Komunikat Komisji do Parlamentu Europejskiego, Rady, Europejskiego Komitetu Ekonomiczno-Społecznego i Komitetu Regionów, Odnowiona strategia Unii Europejskiej na lata 2011-2014 dotycząca społecznej odpowiedzialności przedsiębiorstw, Bruksela, http://eur-lex.europa.eu, last accessed 2016/09/10.

14. Koneczna, R.: CSR i jego narzędzia jako element strategii firm - praktyczny przewodnik, Wydawnictwo IGSMiE PAN, Kraków (2014).

15. Nakoneczna, J. Społeczna odpowiedzialność przedsiębiorstw międzynarodowych, Diffin, Warszawa (2008).

16. Paliwoda-Matioliańska, A.: Odpowiedzialność społeczna w procesie zarządzania przedsiębiorstwem, Wydawnictwo C.H.Beck, Warszawa (2014).

17. Skrzypek, E., Saadi, N.: Motywacje versus korzyści CSR z perspektywy polskich spółek giełdowych, Zeszyty Naukowe Uniwersytetu Przyrodniczo-Humanistycznego w Siedlcach, Seria: Administracja i Zarządzanie, nr 103/2014.

18. Wolska, G.: Corporate Social Responsibility in Poland - theory and practice, Journal of International Studies, Vol. 6 No 2, 2013

19. World Business Council for Sustainable Development, Corporate Social Responsibility: Making Good Business Sense, January 2000, http://www.wbcsd.ch [access:10.09.2016].

20. Woźniczka, J.: Edukacja na rzecz społecznej odpowiedzialności biznesu w Polsce i Europie. In P.Kulawczuk, A.Poszewicki (eds.) Wpływ społecznej odpowiedzialności biznesu i etyki na zarządzanie przedsiębiorstwami, Wydawnictwo Fundacja Rozwoju Uniwersytetu Gdańskiego, Gdańsk (2007).

21. Fundacja Partnerstwo dla Środowiska, http:www.fpds.pl last accessed 2016/10/09.

22. Zbiegień-Maciąg, L.: Etyka w zarządzaniu, Warszawa (1991). 